p-ISSN: $2338-4794$

e-ISSN: 2579-7476

Vol.9. No. 1 Januari-April 2021

\title{
PENGARUH KUALITAS BAHAN BAKU DAN PROSES PRODUKSI TERHADAP KUALITAS PRODUK PT. MENJANGAN SAKTI
}

\author{
Diovita Hilary 1 ) \\ 1) Mahasiswa Program Studi Manajemen FE UNKRIS \\ Imam Wibowo ${ }^{2)}$ \\ 2) Dosen Program Studi Manajemen FE UNKRIS \\ Alamat: Kampus UNKRIS, Jatiwaringin Jakarta Timur \\ Email : wibowoimam253@gmail.com
}

\begin{abstract}
This study aims to analyze the effect of the quality of raw materials on product quality at PT. Menjangan Sakti, the influence of the production process on product quality at PT. Menjangan Sakti and the quality of raw materials and production processes simultaneously on product quality at PT. Menjangan Sakti. The number of samples in this study were 88 respondents. The analysis technique uses simple regression analysis and multiple regression. The results showed that the quality of raw materials and the production process simultaneously had a significant effect on product quality, because the quality of raw materials was maintained in terms of room temperature according to the type of raw materials stored and the production process where workers worked according to applicable regulations. The quality of raw materials has a positive effect on product quality. This shows that the quality of raw materials that are maintained in terms of room temperature according to the type of raw material stored can improve product quality. The production process has a positive effect on product quality. This shows that the workforce working according to the applicable regulations can significantly improve product quality.
\end{abstract}

Keywords: Quality of raw materials, production process, product quality

\section{PENDAHULUAN}

Pesatnya perkembangan bisnis yang semakin ketat mendorong perusahaan harus dapat menjalankan strategi bisnisnya yang tepat agar mampu bertahan dalam menghadapi persaingan yang terjadi. Setiap strategi harus mampu mendukung perusahaan berkompetisi di dalam industrinya. Oleh karena itu, perusahaan harus memberikan perhatian penuh terhadap kualitas produk yang dihasilkan agar perusahaan mampu memenangkan atau paling tidak bertahan di dalam kompetisi tersebut. Dengan menghasilkan produk yang berkualitas, berarti perusahaan mampu melakukan kegiatan produksi dengan efektif dan efisien. Produk yang dihasilkan sesuai dengannkebutuhan dan harapan konsumen sehingga jumlah produk defect atau barang cacat dapat ditekan sekecil mungkin (zero waste). Sehingga dengann menghasilkan produk yang berkualitas, perusahaan akan mendapatkan predikat yang baik di mata konsumen. Bahkan tidak menutup kemungkinan produk akan cepat berekspansi ke pasar global. Kualitas produk menurut Assauri (2012) "merupakan faktor yang terdapat dalam suatu barang atau hasil yang menyebabkan barang tersebut sesuai dengan tujuan untuk apa barang itu dimaksudkan atau dibutuhkan". Selanjutnya menurut Heizer dan Render (2011) "kualitas produk merupakan keseluruhan fitur dan karakteristik produk atau layanan yang dikenakan pada kemampuannya untuk memenuhi kebutuhan yang tampak jelas maupun 
tersembunyi". Secara sederhana kualitas produk yang ditetapkan oleh perusahaan merupakan suatu keadaan yang terbaik, yang berguna untuk memenuhi kebutuhan dan keinginan konsumen. Kepuasan konsumen merupakan salah satu tujuan dari perusahaan dalam memproduksi suatu produk atau barang.

$\begin{array}{lr}\text { Dalam meningkatkan kualitas } \\ \text { produk, perusahaan akan } & \text { lebih } \\ \text { memperhatikan faktor-faktor } & \text { yang } \\ \text { mempengaruhinya. Menurut Garvin }\end{array}$
(1983) "terdapat beberapa faktor yang mempengaruhi kualitas produk seperti, Performances (kinerja), Features (fitur), Reliability (kepercayaan suatu produk), Durability (daya tahan), Aesthetics (estetika)". Selain itu, terdapat faktor penting di dalamnya seperti kualitas bahan baku dan proses produksi yang juga mempengaruhi kualitas produk. Ketersediaan bahan baku sangat penting dalam proses produksi. Menurut Assauri (2012) "kualitas merupakan faktor-faktor yang terdapat dalam suatu barang atau hasil yang menyebabkan barang atau hasil tersebut sesuai dengan tujuan untuk apa baranggatau hasil itu dimaksudkan". Selanjutnya menurut Assauri (2012) "tentang bahan baku merupakan semua bahan yang digunakan dalam perusahaan manufaktur, kecuali untuk bahan yang secara fisik dikombinasikan dengan produk yang diproduksi oleh perusahaan manufaktur ini". Keberhasilan perusahaan tergantung dalam pengadaan bahan baku, upaya untuk mencari dan memilih dengan teliti bahan baku yang akan digunakan dalam proses produksi. Sehingga pemilihan bahan baku yang berkualitas akan berpengaruh pula dengan kualitas produk yang dihasilkan. Peningkatan kualitas bahan baku dan kualitas produk sangat penting untuk memperoleh produk yang sesuai dengan standar kualitas yang diharapkan.

Pelaksanaan proses produksi yang baik dan lancar sangat berpengaruh terhadap kualitas produk yang dihasilkan perusahaan tersebut. Karena proses produksi merupakan metode atau cara bagaimana kegiatan penambahan manfaat atau penciptaan manfaat tersebut dilaksanakan. Menurut Irhami (2014) "proses produksi merupakan sesuatu yang dihasilkan oleh suatu perusahaan baik bentuk barang (goods) maupun jasa (service) dalam suatu periode waktu yang selanjutnya dihitung sebagai nilai tambah bagi perusahaan". Sedangkan menurut Assauri (2012) proses produksi "merupakan cara, metode, dan teknik untuk menciptakan atau menambah kegunaan suatu barang atau jasa dengan menggunakan sumber-sumber (tenaga kerja, mesin, bahan-bahan, dana) yang ada". Dengan selalu tersedianya bahan baku yang berkualitas dan proses produksi yang lancar maka diharapkan perusahaan dapat menghasilkan produk yang berkualitas sesuai dengan kebutuhan atau permintaan konsumen.

Teori-teori diatas didukung dengan penelitian yang dilakukan oleh Satar dan Israndi (2019) menghasilkan penelitiannya yaitu kualitas bahan baku memberikan pengaruh yang positif dan signifikan terhadap kualitas produk pada perusahaan manufaktur. Dengan demikian kualitas bahan baku memberikan kontribusi positif yang dapat menentukan kualitas pada perusahaan tersebut, artinya semakin baik kualitas bahan baku maka akan semakin baik kualitas produk demikian pula sebaliknya. Selanjutnya penelitian yang dilakukan oleh Noerpratomo (2018) menghasilkan penelitiannya yaitu terdapat pengaruh proses produksi terhadap kualitas produk pintu air irigasi pada perusahaan manufaktur, hal ini terlihat dari proses produksi pembuatan pintu irigasi yang baik akan menghasilkan kualitas produk pintu air irigasi yang baik juga. Dan Penelitian yang dilakukan oleh Sentosa dan Trianti (2017) menghasilkan penelitiannya yaitu secara parsial dan simultan kualitas bahan baku dan proses 
produksi mempunyai pengaruh yang positif dan signifikan terhadap kualitas produk. Kunci produk yang berkualitas pada proses produksi yang terintegrasi dengan variabel kualitas bahan baku dan tenaga kerja. Tenaga kerja yang handal dan kualitas bahan baku yang terpilih akan memperlancar proses produksi yang dikawal dengan quality control yang ketat. Hal tersebut pada akhirnya akan menghasilkan produk yang berkualitas tinggi. Dari beberapa hasil penelitian terdahulu di atas yang menyerupai, maka hasil dari penelitian tersebut sangat membantu dan mendukung untuk penelitian pengaruh kualitas bahan baku dan proses produksi terhadap kualitas produk PT. Menjangan Sakti.

PT. Menjangan Sakti beralamat kan di Kawasan Industri Pulogadung, JL. Pulo Ayang, Kav II R-31 Jakarta 13930 Indonesia. PT. Menjangan Sakti menghasilkan produk seperti kosmetik (bahan dasar), pangan (perasa), pakan ternak dan farmasi (bahan aktif). PT. Menjangan Sakti selalu berusaha untuk memenuhi kebutuhan konsumen terutama dalam kualitas produk. Perusahaan beberapa tahun terakhir mengalami penurunan penjualan hasil produksi dimana kualitas produk menjadi sorotan utama. Hal itu dapat dilihat dari tabel berikut:

Tabel 1: Kualitas Produk

\begin{tabular}{ccccc}
\hline Tahun & Bahan Baku & Jumlah Produksi & Produk Berkualitas & Produk Gagal \\
\hline 2015 & $190 \mathrm{~kg}$ & $2318 \mathrm{pcs}$ & $2202 \mathrm{pcs}$ & $116 \mathrm{pcs}(5 \%)$ \\
2016 & $190 \mathrm{~kg}$ & $2318 \mathrm{pcs}$ & $2214 \mathrm{pcs}$ & $104 \mathrm{pcs}(4,5 \%)$ \\
2017 & $190 \mathrm{~kg}$ & $2318 \mathrm{pcs}$ & $2202 \mathrm{pcs}$ & $116 \mathrm{pcs}(5 \%)$ \\
2018 & $190 \mathrm{~kg}$ & $2318 \mathrm{pcs}$ & $2156 \mathrm{pcs}$ & $162 \mathrm{pcs}(7 \%)$ \\
2019 & $190 \mathrm{~kg}$ & $2318 \mathrm{pcs}$ & $2133 \mathrm{pcs}$ & $185 \mathrm{pcs}(8 \%)$ \\
\hline
\end{tabular}

Sumber : data primer PT. Menjangan Sakti Tahun 2020.

Dari Tabel 1, dapat kita lihat bahwa, PT Menjangan Sakti mengalami kegagalan produk yang terus meningkat. Hal ini dapat disebabkan oleh penggantian bahan baku yang dilakukan oleh perusahaan dan kemungkinan ada proses produksi yang tidak sesuai standar operasional produksi.

Tujuan penelitian ini adalah untuk mengetahui pengaruh kualitas bahan baku dan proses produksi terhadap kualitas produk PT. Menjangan Sakti.

\section{LANDASAN TEORI}

\section{Kualitas Produk}

Menurut Assauri (2012) kualitas produk merupakan faktor yang terdapat dalam suatu barang atau hasil yang menyebabkan barang tersebut sesuai dengan tujuan untuk apa barang itu dimaksudkan atau dibutuhkan. Menurut Heizer dan Render (2011) kualitas produk merupakan keseluruhan fitur dan karakteristik produk atau layanan yang dikenakan pada kemampuannya untuk memenuhi kebutuhan yang tampak jelas maupun tersembunyi. Menurut Goetdch dan Davis (2002), kualitas produk merupakann suatu kondisi dinamis yang berhubungan dengan barang, jasa, manusia, produk dan lingkungan yang memenuhi atau melebihi harapan. Menurut Nasution (2005), kualitas produk merupakan suatu kondisi dinamis yang berhubungan dengan produk, manusia/tenaga kerja, proses dan tugas, serta lingkungan yang memenuhi atau melebihi harapan konsumen. Menurut Prawirosentono (2002), kualitas produk merupakan keadaan fisik, fungsi dan sifat suatu produk bersangkutan yang dapat memenuhi selera dan kebutuhan konsumen dengan memuaskan sesuai nilai uang yang dikeluarkan. 
Kualitas produk merupakan salah satu kunci persaingan diantara pelaku usaha yang ditawarkan kepada konsumen. Konsumen selalu ingin mendapatkan produk yang berkualitas sesuai dengan harga yang dibayar, walaupun terdapat sebagian masyarakat yang berpendapat bahwa, produk yang mahal adalah produk yang berkualitas. Jika hal itu dapat dilaksanakan oleh perusahaan, maka perusahaan tersebut akan tetap memuaskan para konsumen dan dapat menambah jumlah konsumen. Kualitas produk merupakan hal penting yang harus diusahakan oleh setiap perusahaan apabila menginginkan produk yang dihasilkan dapat bersaing di pasar. Adanya hubungan timbal balik antara perusahaan dengan konsumen akan memberikan peluang untuk mengetahui dan memahami apa yang menjadi kebutuhan dan harapan yang ada pada persepsi konsumen. Maka, perusahaan penyedia produk dapat memberikan kinerja yang baik untuk mencapai kepuasan konsumen melalui cara memaksimalkan pengalaman yang menyenangkan dan meminimalisir pengalaman yang kurang menyenangkan konsumen dalam mengkonsumsi produk.

Manfaat yang diperoleh dengan menciptakan kualitas produk antara lain: 1). Meingkatkan reputasi perusahaan. 2). Menurunkan biaya. 3). Meningkatkan pangsa pasar. 4). Dampak internasional. 5). Adanya tanggung jawab produk. 6). Untuk penampilan produk.

Mewujudkan kualitas yang dirasakan penting.

Lima tingkatan dalam kualitas produk antara lain: 1). Manfaat inti (Core Benefit). Yaitu jasa atau manfaat inti sesungguhnya yang dibeli dan diperoleh oleh konsumen. 2). Manfaat dasar tambahan (Basic Product). Tingkat selanjutnya seorang pemasar harus mampu merubah manfaat inti menjadi produk dasar. 3). Harapan produk (Expected Product). Adalah serangkaian kondisi yang diharapkan dan disenangi, dimiliki atribut produk tersebut.

4). Kelebihan yang dimiliki produk (Augmented Product). Yaitu salah satu manfaat dan pelayanan yang dapat membedakan produk tersebut dengan pesaing. 5). Potensi masa depan produk (Potensial Product). Artinya bagaimana harapan masa depan dengan produk tersebut apabila terjadi perubahan dan perkembangan teknologi serta selera konsumen.

Indikator dari kualitas produk menurut Garvin (1983), antara lain: 1). Performances (kinerja) Kinerja merupakan karakteristik atau fungsi utama suatu produk. Dalam memilih suatu produk biasanya konsumen melihat kinerja suatu produk sebagai faktor utama sebelum melakukan pembelian, apakah produk tersebut mampu memenuhi kebutuhan konsumen atau tidak. 2). Features (fitur) merupakan karakteristik produk yang dirancang untuk menyempurnakan fungsi produk dan menambah ketertarikan konsumen terhadap suatu produk. Fitur bersifat pilihan bagi konsumen dan tidak seluruhnya harus digunakan. Apabila manfaat utama sudah standar fitur seringkali ditambahkan agar mejadi nilai lebih agar bisa mengungguli produk lain dalam pasar yang sama. 3). Reliability (kepercayaan suatu produk) Reliabilitas adalah probabilitas bahwa produk akan bekerja dengan memuaskan atau tidak dalam periode waktu tertentu. Semakin kecil kemungkinan terjadinya kerusakan maka produk tersebut dapat diandalkan. 4). Durability (daya tahan) merupakan kemampuan produk dalam bertahan dalam penggunaan jangka waktu tertentu. Semakin lama daya tahan suatu produk maka semakin baik pula reputasi produk tersebut dimata konsumen. 5). Aesthetics (estetika) Estetika biasanya berhubungan terhadap desain sebuah produk. Namun tak hanya itu, bau, rasa dan bentuk juga termasuk dalam estetika sebuah produk. Estetika menjadi hal penting karena hal itu 
merupakan interaksi langsung antara konsumen dan produk yang dikonsumsinya.

\section{Kualitas Bahan Baku}

Menurut Assauri (2012) "kualitas merupakan faktor-faktor yang terdapat dalam suatu barang atau hasil yang menyebabkan barang atau hasil tersebut sesuai dengan tujuan untuk apa barang atau hasil itu dimaksudkan". Menurut Syukron dan Kholil (2012) menyebutkan beberapa definisi kualitas antara lain: 1). Kualitas berarti layak digunakan. Ada dua aspek dari definisi ini yaitu quality of design and quality of performance. Quality design adalah level dari kualitas, yaitu spesifikasi produk yang dibuat berdasarkan keiinginan dari konsumen, sedangkan quality of performance adalah seberapa baik suatu produk dalam memenuhi spesifikasi dari permintaan dengan desainnya. 2). Kualitas adalah berbanding terbalik dengan variabilitas artinya kualitas produk akan meningkat jika variabilitas dalam karakteristik penting suatu produk menurun.

Menurut Assauri (2012) "bahan baku merupakan semua bahan yang digunakan dalam perusahaan manufaktur, kecuali untuk bahan yang secara fisik dikombinasikan dengan produk yang diproduksi oleh perusahaan manufaktur ini". Menurut Handoko (2005) "kualitas merupakan suatu kondisi dari sebuah barang berdasarkan pada penilaian atas kesesuaiannya dengan standar ukur yang telah ditetapkan". Menurut Wibowo (2007) "bahan baku meliputi semua barang dan bahan yang dimiliki perusahaan dan digunakan untuk proses produksi".

Kualitas atau mutu adalah tingkat baik buruknya atau taraf atau derajat sesuatu. Istilah ini banyak digunakan dalam dunia bisnis, rekayasa, dan manufaktur dalam kaitannya dengan teknik dan konsep untuk memperbaiki kualitas produk atau jasa yang dihasilkan, seperti Six Sigma, TQM, Kaizen, dan lainlain. Secara umum dapat dikatakan bahwa kualitas atau mutu adalah karakteristik dari suatu produk atau jasa yang ditentukan oleh pemakai atau customer dan diperoleh melalui pengukuran proses serta melalui perbaikan yang berkelanjutan (Continuous Improvement). Serta merupakan salah satu faktor yang dipakai oleh konsumen untuk membeli suatu produk, yang mana suatu produk dapat dibandingkan dengan pesaingnya berdasarkan kualitasnya.

Faktor-faktor yang mempengaruhi kualitas antara lain adalah bahan baku, peralatan, teknologi dan sumber daya manusia. Perbedaan arti kata antara bahan baku dan bahan mentah dapat mempunyai arti sebagai sebuah bahan dasar yang berada di berbagai tempat, yang mana bahan tersebut dapat digunakan untuk diolah dengan suatu proses tertentu ke dalam bentuk lain yang berbeda wujud dari bentuk aslinya.

Indikator kualitas bahan baku menurut Situmorang (2016) adalah: 1). Penyimpanan merupakan salah satu hal penting yang berperan didalam menjaga mutu bahan. 2). Penanganan/ pengendalian merupakan suatu seni dan ilmu untuk memindahkan, membungkus dan menyimpan bahan-bahan dalam segala bentuk. 3). Proses merupakan kegiatan mengubah barang mentah menjadi barang yang memiliki nilai jual. Proses ini harus berjalan sesuai standar operasional yang berlaku serta melalui quality control sebagai tahap akhir yang ditetapkan perusahaan.

\section{Proses Produksi}

Menurut Irhami (2014) "proses produksi merupakan sesuatu yang dihasilkan oleh suatu perusahaan baik bentuk barang (goods) maupun jasa (service) dalam suatu periode waktu yang selanjutnya dihitung sebagai nilai tambah bagi perusahaan". Menurut Assauri (2012) "proses produksi merupakan cara, 
metode, dan teknik untuk menciptakan atau menambah kegunaan suatu barang atau jasa dengan menggunakan sumbersumber (tenaga kerja, mesin, bahanbahan, dana) yang ada". Menurut Heizer dan Render (2011) "proses produksi merupakan cara, metode ataupun teknik bagaimana produksi itu dilaksanakan serta kegiatan untuk menambah kegunaan suatu barang dan jasa dengan menggunakan faktor produksi yang ada". Menurut Yamit (2011) "proses produksi merupakan pengubahan (transformasi) dari bahan atau komponen (input) menjadi produk lain yang mempunyai nilai tinggi atau dalam proses terjadi penambahan nilai". Setiap bagian dari organisasi yang mengambil input dan mengolahnya menjadi output yang diharapkan akan memiliki nilai tambah bagi organisasi dibandingkan dengan input awalnya dapat disebut sebagai proses produksi. Serta suatu kegiatan yang menggabungkan berbagai faktor produksi yang ada dalam upaya menciptakan suatu produk, baik itu barang atau jasa yang memiliki manfaat bagi konsumen. Proses produksi disebut juga sebagai kegiatan mengolah bahan baku dan bahan pembantu dengan memanfaatkan peralatan sehingga menghasilkan suatu produk yang lebih bernilai dari bahan awalnya.

Dalam pelaksanaannya, proses ini memerlukan waktu yang berbeda-beda, ada yang singkat, dan ada juga yang prosesnya cukup panjang. Berdasarkan cara pelaksanaannya, proses produksi dapat dibedakan menjadi empat jenis, yaitu: 1). Produksi jangka pendek, Ini adalah kegiatan produksi yang cepat dan langsung menghasilkan produk (barang/ jasa) bagi konsumen. Contohnya adalah produksi makanan seperti roti bakar, cakwe, gorengan, dan lain-lain.

2).

Produksi jangka panjang, Ini adalah kegiatan produksi yang membutuhkan waktu yang cukup lama. Misalnya, menanam padi, menanam kopi, membangun rumah, dan lain-lain. 3).
Produksi terus-menerus, Ini adalah kegiatan produksi yang melakukan pengolahan berbagai bahan baku secara bertahap hingga menjadi suatu barang jadi, dimana prosesnya berlangsung secara terus menerus. Misalnya, pabrik yang memproduksi kertas, gula, karet, dan lain-lain. 4). Produksi berselingan, Ini adalah kegiatan produksi yang mengolah bahan-bahan baku dengan cara menggabungkannya menjadi suatu barang jadi. Misalnya proses pembuatan sepeda motor, dimana setiap bagiannya diproduksi secara terpisah (stir, ban, mesin, knalpot, dan lainnya). Proses penggabungan bagian-bagian tersebut menghasilkan sebuah sepeda motor.

Indikator dari proses produksi menurut Assauri (2012) antara lain: 1). Tenaga kerja, pelaksana pengoperasian suatu system produksi dan operasi yang mempunyai keterampilan dan kemampuan untuk melaksanakan nyata atau orang mengerjakan kegiatannuntuk menghasilkan produk, berupa barang atau jasa. 2). Mesin-mesin, adalah suatu peralatan yang digerakan oleh suatu kekuatan / tenaga yang dipergunakan untuk membantu manusia dalam mengerjakan produk atau bagian-bagian produk. 3). Bahan-bahan, kebutuhan yang dipakai untuk kegiatan produksi menjadi produk setengah jadi atau produk jadi sehingga menambah kegunaan atau fungsi. 4). Dana, hak para pemilik dalam suatu perusahaan.

\section{METODE PENELITIAN}

Penelitian ini menggunakan metode kuantitatif untuk mengukur pengaruh kualitas bahan baku dan proses produksi terhadap kualitas produk PT. Menjangan Sakti.

Populasinya adalah karyawan bagian produksi dari PT. Menjangan Sakti yang berjumlah 131 orang. Pengukuran atau menentukan jumlah sampel dalam penelitian ini penulis menggunakan rumus 
Isaac dan Michael yaitu sebagai berikut: Berdasarkan populasi dengan jumlah populasi 131 orang dengan tingkat kesalahan $10 \%$, maka diperoleh ukuran atau jumlah sampel dalam penelitian ini sebesar 88 (delapan puluh delapan) karyawan bagian produksi. Dengan jumlah data karyawan PT. Menjangan Sakti diatas, maka dalam penelitian ini menggunakan metode teknik sampel yaitu sampel Probability sampling. Metode analisis yang digunakan adalah regresi linear sederhana dan berganda dan sebelum dilakukan analisis data terlebih dahulu dilakuan pengujian instrumen data.

\section{HASIL PENELITIAN DAN PEMBAHASAN}

\section{Hasil Penelitian}

\section{Uji Instrumen}

Pada penelitian ini langkah awal yang dilakukan yaitu dengan melakukan uji validitas dan uji reliabilitas atas instrumen-instrumen dari pernyataan kuesioner yang telah disebarkan ke responden secara langsung dan tertutup. Dengan dilakukan pengujian data validitas dan reliabilitas, maka kualitas penelitian dapat terjaga serta fakta dan keadaan sebenarnya tentang "Pengaruh Kualitas Bahan Baku dan Proses Produksi Terhadap Kualitas Produk di PT. Menjangan Sakti”.

\section{Uji Validitas Data}

Uji validitas merupakan derajat ketepatan antara data yang sesungguhnya terjadi pada objek penelitian dengan data yang dapat dilaporkan oleh peneliti. Instrumen yang valid berarti alat ukur yang digunakan untuk mendapatkan data (mengukur) itu valid. Valid berarti instrument tersebut dapat digunakan untuk mengukur apa yang sebenarnya diukur. Jika $r \geq 0,30$, maka item instrumen dinyatakan valid, dan Jika $r \leq 0,30$, maka item instrument dinyatakan tidak valid.

Berdasarkan dari hasil uji validtas terlihat bahwa korelasi masing-masing indikator dari kualitas bahan baku, proses produksi dan kualitas produk didapatkan total skor pernyataan menunjukkan hasil yang signifikan. Dikatakan signifikan karena apabila $r$ hitung $>r$ tabel dan $r \geq$ 0,30, maka item instrumen dinyatakan valid.

\section{Uji Reliabilitas}

Menurut Sugiyono (2018) uji reliabilitas merupakan "instrumen yang bila digunakan beberapa kali untuk mengukur obyek yang sama, akan menghasilkan data yang sama”. Reliabilitas dapat dicari dengan menggunakan teknik Croncbach's alpha. Dari hasil uji reliabilitas terlihat bahwa masing-masing variabel menunjukkan hasil yang signifikan. Data dikatakan reliabel apabila Jika nilai reliabilitasnya lebih besar dari 0.60, maka secara keseluruhan variabel kualitas bahan baku, proses produksi dan kualitas produk nilainya lebih besar dari 0.60 dan dinyatakan reliabel, seperti dalam tabel 2.

Tabel 2: Hasil Uji Reliabilitas Variabel

\begin{tabular}{lcc}
\hline \multicolumn{1}{c}{ Variabel } & Cronbach's Alpha & Keterangan \\
\hline Kualitas Bahan Baku & 0.710 & Reliabel \\
Proses Produksi & 0.664 & Reliabel \\
Kualitas Produk & 0.748 & Reliabel \\
\hline
\end{tabular}

Sumber: Hasil pengolahan data, 2021 


\section{Analisis Hasil Penelitian}

Tabel 3: Pengaruh Kualitas Bahan Baku dan Proses Produksi Terhadap Kualitas Produk

\begin{tabular}{|c|c|c|c|c|c|}
\hline \multirow[b]{2}{*}{ Variabel } & \multicolumn{5}{|c|}{ Parameter } \\
\hline & $\begin{array}{c}\mathbf{R} \\
\text { Square }\end{array}$ & Konstanta & $\begin{array}{c}\text { Koefisien } \\
\text { Regresi }\end{array}$ & Sig. & $\alpha$ \\
\hline $\begin{array}{l}\text { Kualitas Bahan Baku } \\
\text { Proses Produksi }\end{array}$ & 0,460 & 0,640 & $\begin{array}{l}0,387 \\
0,567\end{array}$ & $\begin{array}{l}0,000 \\
0,000\end{array}$ & 0,01 \\
\hline
\end{tabular}

\section{Pengujian Signifikan}

F hitung $>$ F tabel $=36,152>3,10$

Keterangan: Variabel Kualitas Produk

Sumber: data diolah 2021

Berdasarkan Tabel 3, nilai F hitung sebesar 36,152 dan $\mathrm{F}$ tabel 3,10, maka Ho ditolak dan $\mathrm{Ha}$ diterima artinya ada pengaruh secara simultan kualitas bahan baku dan proses produksi terhadap kualitas produk. Nilai R Square sebesar 0,460 , dapat diartikan terdapat kontribusi secara simultan kualitas bahan baku dan proses produksi terhadap kualitas produk PT. Menjangan Sakti sebesar sebesar $46,0 \%$, sedangkan sisanya sebesar $54,0 \%$ disumbangkan variabel lain yang tidak diteliti. berikut:

Hasil persamaan regresi sebagai

Tabel 4: Pengaruh Kualitas Bahan Baku Terhadap Kualitas Produk

\begin{tabular}{lccccc}
\hline \multirow{2}{*}{ Variabel } & $\begin{array}{c}\text { R } \\
\text { Square }\end{array}$ & Konstanta & $\begin{array}{c}\text { Koefisien } \\
\text { Regresi }\end{array}$ & Sig & $\boldsymbol{\alpha}$ \\
\hline Kualitas Bahan Baku & 0,230 & 18,359 & 0,523 & 0,000 & 0.01 \\
\hline Pengujian Signifikan & & & & & \\
\hline t hitung > t tabel = 5,064 > 1,988 & & & \\
\hline Keterangan: Variabel Kualitas Produk \\
Sumber: data diolah 2021
\end{tabular}

Berdasarkan Tabel 4, nilai R Square sebesar 0,230, dapat diartikan konstribusi yang diberikan kualitas bahan baku terhadap kualitas produk PT. Menjangan Sakti sebesar 23,0\%, sedangkan sisanya sebesar $77,0 \%$ disumbangkan variabel

$$
Y=0,640+0,387\left(X_{1}\right)+0,567\left(X_{2}\right)
$$

Kualitas bahan baku dan proses produksi berpengaruh positif dan signifikan terhadap kualitas produk PT. Menjangan Sakti pada tingkat nyata $99 \%$. Koefisien kualitas bahan baku sebesar 0,387, artinya jika ada peningkatan kualitas bahan baku, maka kualitas produk PT. Menjangan Sakti akan meningkat atau sebaliknya dengan asumsi proses produksi tidak berubah. Koefisien proses produksi sebesar 0,567, artinya jika ada perbaikan proses produksi, maka maka kualitas produk PT. Menjangan Sakti akan meningkat atau sebaliknya, dengan asumsi kualitas bahan baku tidak berubah. lain yang tidak diteliti, seperti proses produksi. berikut:

Hasil persamaan regresi sebagai

$$
\mathrm{Y}=18,359+0,523\left(\mathrm{X}_{1}\right)
$$


Kualitas bahan baku berpengaruh positif dan signifikan pada tingkat nyata 99\% terhadap kualitas produk PT. Menjangan Sakti. Koefisien kualitas bahan baku sebesar 0,523 , artinya jika ada peningkatan kualitas bahan baku, maka kualitas produk PT. Menjangan Sakti akan meningkat atau sebaliknya.

Tabel 5: Pengaruh Proses Produksi Terhadap Kualitas Produk

\begin{tabular}{lccccc}
\hline \multirow{2}{*}{ Variabel } & $\begin{array}{c}\mathbf{R} \\
\text { Square }\end{array}$ & Konstanta & $\begin{array}{c}\text { Koefisien } \\
\text { Regresi }\end{array}$ & Sig & $\boldsymbol{\alpha}$ \\
\cline { 2 - 6 } & 0,342 & 12,351 & 0,669 & 0,000 & 0.01 \\
\hline Proses Produksi & \multicolumn{10}{c}{} & & & \\
\hline Pengujian Signifikan & & & & \\
\hline t hitung > t tabel = 6,678 $>1,988$ \\
\hline $\begin{array}{l}\text { Keterangan: Variabel Kualitas Produk } \\
\text { Sumber: data diolah 2021 }\end{array}$
\end{tabular}

Berdasarkan Tabel 5, nilai R Square sebesar 0,342, dapat diartikan konstribusi yang diberikan proses produksi terhadap kualitas produk PT. Menjangan Sakti sebesar 34,2\%, sedangkan sisanya sebesar $65,8 \%$ disumbangkan variabel lain yang tidak diteliti, seperti kualitas bahan baku. berikut:

Hasil persamaan regresi sebagai

$$
\mathrm{Y}=12,351+0,669\left(\mathrm{X}_{2}\right)
$$

Proses produksi berpengaruh positif dan signifikan pada tingkat nyata 99\% terhadap kualitas produk PT. Menjangan Sakti. Koefisien proses produksi sebesar 0,669 , artinya jika ada peningkatan proses produksi, maka kualitas produk PT. Menjangan Sakti akan meningkat atau sebaliknya. Nilai t hitung lebih besar dari t tabel $(6.678>1,988)$, maka Ho tolak, Ha terima, artinya ada pengaruh yang positif dan signifikan proses produksi terhadap kualitas produk PT. Menjangan Sakti.

\section{Pembahasan}

\section{Pengaruh Kualitas Bahan Baku dan Proses Produksi Terhadap Kualitas Produk}

Berdasarkan hasil penelitian diperoleh bahwa kualitas bahan baku dan proses produksi mendorong peningkatan kualitas produk, karena kualitas bahan baku terjaga dari segi kebersihan sangat penting dalam penyimpanan bahan baku, bahan baku disimpan secara berurutan sesuai dengan jenisnya, Suhu ruangan disesuaikan dengan jenis bahan baku yang disimpan, bahan baku yang diterima tergolong efisien, bahan baku yang diterima telah teruji aman, kapasitas bahan baku terhitung efektif, bahan baku yang diterima sudah terjadwal, penerimaan bahan baku sesuai dengan SOP yang berlaku, penyaluran bahan baku lancer. Serta didukung oleh tenaga kerja yang terampil, bekerja sama dengan tim, bekerja sesuai aturan yang berlaku, biaya mesin rendah dalam pengolahan bahan baku, mesin baru yang yang digunakan dalam pengolahan bahan baku, perawatan mesin dilakukan berkala, bahan baku yang diolah berkualitas, bahan baku yang diperoleh cukup murah, mudah dalam memperoleh bahan baku yang dibutuhkan. Hal tersebut sesuai dengan hasil penelitian yang dilakukan oleh Sentosa dan Trianti (2017) dengan hasil penelitiannya yaitu secara parsial dan simultan kualitas bahan baku dan proses produksi mempunyai pengaruh yang positif dan signifikan terhadap kualitas produk. Kunci produk yang berkualitas pada proses produksi yang terintegrasi dengan variabel kualitas bahan baku. Kualitas bahan baku yang terpilih akan memperlancar proses produksi yang dikawal dengan quality 
control yang ketat. Hal tersebut pada akhirnya akan menghasilkan produk yang berkualitas tinggi.

\section{Pengaruh Kualitas Bahan Baku Terhadap Kualitas Produk}

Berdasarkan hasil penelitian diperoleh kualitas bahan baku mendorong peningkatan kualitas produk, karena kualitas bahan baku terjaga dari segi penyimpanan dengan memperhatikan kebersihan yang sangat penting, secara berurutan sesuai dengan jenisnya, dan suhu ruangan disesuaikan dengan jenis bahan baku yang disimpan dalam penyimpanan bahan baku. Hal tersebut sesuai hasil penelitian yang dilakukan oleh Satar dan Israndi (2019) menghasilkan penelitiannya yaitu kualitas bahan baku memberikan pengaruh yang positif dan signifikan terhadap kualitas produk. Dengan demikian kualitas bahan baku memberikan kontribusi positif yang dapat menentukan kualitas, artinya semakin baik kualitas bahan baku maka akan semakin baik kualitas produk demikian pula sebaliknya.

\section{Pengaruh Proses Produksi Terhadap Kualitas Produk}

Berdasarkan hasil penelitian diperoleh proses produksi mendorong peningkatan kualitas produk. Hal ini terbukti dengan di dukungnya tenaga kerja yang terampil, dapat bekerja sama dengan tim, dan bekerja sesuai aturan yang berlaku. Hal tersebut sesuai dengan penelitian yang dilakukan oleh Noerpratomo (2018) dengan hasil penelitian terdapat pengaruh proses produksi terhadap kualitas produk pintu air irigasi, hal ini terlihat dari proses produksi pembuatan pintu irigasi yang baik akan menghasilkan kualitas produk pintu air irigasi yang baik juga. Karena proses produksi merupakan salah satu faktor yang sangat menetukan baik buruknya kualitas produk yang dihasilkan oleh perusahaan.

\section{KESIMPULAN DAN SARAN}

\section{Kesimpulan}

Berdasarkan hasil penelitian yang telah dilakukan dan telah dibahas dalam pembahasan, maka dapat diambil kesimpulan yang dapat diuraikan sebagai berikut: 1). Kualitas bahan baku dan proses produksi mendorong peningkatan kualitas produk. 2). Kualitas bahan baku mendorong peningkatan kualitas produk. 3). Proses produksi mendorong peningkatan kualitas produk.

\section{Saran}

1. Untuk Perusahaan; Dengan adanya penelitian ini diharapkan dapat menambah bahan masukan positif khususnya untuk manajemen atau pimpinan di PT. Menjangan Sakti. Untuk memperoleh atau mendapatkan hasil produk yang berkualitas maka perusahaan harus memperhatikan kualitas bahan baku dari segi spesifikasinya seperti ukuran, kelembapan dan uji klinis dari bahan baku yang diterima. Dalam proses produksi, agar lebih optimal sebaiknya para operator diberi pelatihan dalam pengoperasian mesin - mesin produksi. Serta penjadwal perawatan mesin-mesin dilakukan secara berkala baik mesin baru maupun mesin lama sehingga dalam hal biaya perawatan mesin menjadi rendah dalam pengolahan bahan baku.

2. Bagi Peneliti Selanjutnya; Sebagai referensi untuk penelitian selanjutnya, ada baiknya variable bebas bertambah seperti TQM dan ISO 9001. Sehingga dapat memberikan tambahan dan masukan bagaimana cara mengetahui kualitas produk dari sebuah produksi dalam perusahaan lebih meningkat sehingga tujuan yang diharapkan dapat tercapai dengan baik. 


\section{DAFTAR PUSTAKA}

Assauri, Sofjan. 2012. Manajemen Produksi dan Operasi. Jakarta: Lembaga Penerbit Fakultas Ekonomi Indonesia.

Garvin, David, "Managing Quality", 1983. di dalam Nasution, M.N. 2001. Manajemen Mutu Terpadu (Fotal Quality Management). Jakarta: Ghalia Indonesia

Goetsch, David L. dan Stanley B. Davis. 2002. Total Quality Management, diterjemahkan oleh Benyamin Molan. Total Kualitas Mana:iemen. Jakarta: Penerbit Prenhallindo

Handoko, T. Hani.2008. Dasar-Dasar Manajemen Produksi dan Operasi. Yogyakarta: Penerbit BPFE.

Heizer, Jay and Render, Barry. 2011. Operations Management (Manajemen Operasi). Jakarta: Penerbit Salemba Empat.

Irhami, Fahmi. 2014. Manajemen Produksi dan Operasi. Jakarta: Penerbit Alfabeta.

Nasution. 2005. Manajemen Mutu Terpadu: Total Quality Management. Bogor: Penerbit Ghalia Indonesia.

Noerpratomo, A. 2018. Pengaruh Persediaan Bahan Baku Dan Proses Produksi Terhadap Kualitas Produk Di CV. Banyu Biru Connection. Jurnal Manajemen dan Bisnis (Almana) Vol.2 No.2 , 20-30.

Prawirosentono, Suyadi. 2002. Manajemen Operasi, Analisis dan Studi Kasus. Jakarta: Penerbit Bumi Aksara.

Satar dan Israndi, Adi. 2019. Pengaruh Kualitas Bahan Baku Dan Efisiensi Biaya Produksi Terhadap Kualitas Produk Pada CV. Granville. Jurnal Ilmiah Akuntansi, Volume 10, Nomor 3, Hlm 89-101, SeptemberDesember 2019. P-ISSN 20864159, E-ISSN 2656-6648. Bandung.
Sentosa, Endri dan Trianti, Emalia. 2017. Pengaruh Kualitas Bahan Baku, Proses Produksi dan Kualitas Tenaga Kerja Terhadap Kualitas Produk Pada PT. Delta Surya Energy di Bekasi. Oikonomia: Jurnal Ilmu Manajemen. Vol. 13, No. 2 (2017), hal. 62-71.

Situmorang, Netty Marlyna. 2016. Pengaruh Bahan Baku, SDM, dan Teknologi Terhadap Daya Saing Perusahaan PT. Aquafarm Nusantara (Industri Pengelolaan Ikan Nila) Dengan Kualitas Produk Sebagai Variabel Intervening. Jakarta: Universitas Terbuka.

Sugiyono. 2018. Metode Penelitian Kuantitatif, Kualitatif, dan $R \& D$. Bandung: Penerbit Alfabeta CV.

Syukron, Amin dan Kholil, Muhammad. 2012. Six Sigma Quality For Business Improvement. Penerbit: Graha Ilmu. Jakarta

Wibowo, Singgih. 2007. "Manajemen Produksi ", Edisi Empat. Yogyakarta: Penerbit BPFE.

Yamit, Zulian, 2011. Manajemen Produksi dan Operasi, Edisi Pertama. Yogyakarta: Penerbit Ekonisia. 